\title{
Are Firms Accessing Venture Funding more Financially Constrained? New Evidence from Capital Structure Adjustments
}

\author{
Marina Balboa \\ Financial Economics Department \\ University of Alicante, Spain \\ marina.balboa@ua.es
}

José Martí

Financial Economics and Accounting III Department

University Complutense of Madrid, Spain

jmartipe@ccee.ucm.es

\author{
Alvaro Tresierra \\ Economic Faculty \\ University of Piura, Peru \\ alvaro.tresierra@udep.pe
}

\begin{abstract}
We analyze whether firms that receive Venture Capital (VC) at a later date face more financial constraints than a one-by-one matched sample of firms that did not receive VC funding (control group). The aim is to check whether their financial flexibility explains why they decide to seek external equity funding. In contrast with other papers, which focus on the sensitivity of investments to cash flow, we study this issue by applying a dynamic model to analyze the speed of adjustment to their target debt levels prior to receiving the first VC investment. We analyze a representative sample of 237 Spanish unlisted firms that received VC between 1995 and 2007 and its corresponding control group. We find that firms that receive VC funding show a significantly lower speed of adjustment than their matched peers before the initial VC round. It seems that the former are more concerned about funding the required investments than about adjusting the firm's debt ratio to a target level. Our results confirm the role of VC in filling the equity gap in constrained unlisted firms. From a capital structure perspective, VC may become a tool for these companies to balance their capital structure in a growth process.
\end{abstract}

Keywords: venture capital, capital structure, financial constraints, adjustment speed, growth opportunities.

JEL classification: G32, G24. 


\section{Introduction}

The venture capital (VC) literature has deeply analyzed supply-side issues that justify the role played by VC firms (e.g., Sahlman 1990; Amit et al. 1998; Bessler and Kurth 2007; Reid et al. 2010), as well as the main firm characteristics that are found to be attractive to venture capitalists (VCs)(e.g., Tyebjee and Bruno 1984; Fried and Hisrich 1994). However, there is little research on the financial characteristics of firms that induce them to search for VC (Baeyens and Manigart 2006). The main reason for prospective investee firms to access $\mathrm{VC}$ funding is the lack of financial resources to fund their investment projects. Hence, it is expected that those firms are more financially constrained before the initial round completed by a VC firm (i.e., before receiving treatment). This feature has been evidenced in the VC literature by focusing on the significant sensitivity of investments to cash flows before the initial VC round (e.g., Manigart et al. 2002; Bertoni et al. 2010, 2013; Engel and Stiebale 2014). There is even evidence on the reduction of financial constraints in those firms after the initial VC round (Bertoni et al. 2013; Engel and Stiebale 2014). However, there is methodological controversy in the literature on the relationship between financial constraints and investment-cash flow sensitivity. Kaplan and Zingales (1997, 2000), Kadapakkam et al. (1998) or Cleary $(1999,2006)$ show that least financially constrained firms may also exhibit greater investment-cash flow sensitivity. Later studies indicate that the source of these mixed results lies, among others, in the disagreement among researchers in identifying appropriate factors to segregate more financially constrained firms from less constrained ones (Moyen 2004; Cleary et al. 2007), the fact that the variables used to define financial constraints are time invariant (Hubbard 1998), or the lack of a proper control for the investment opportunities (Alti 2003). 
In this work we aim to provide further support to the evidence on whether VCbacked firms are more financially constrained than a matched sample of non VC-backed firms before receiving treatment by using a new approach: the study of the dynamic behavior of leverage prior to the initial $\mathrm{VC}$ round. We resort to a new strand in the literature on capital structure that relates financial constraints to the speed of adjustment to a target debt ratio (e.g., Flannery and Rangan 2006; Flannery and Hankins 2007; Byoun, 2008; Dang et al. 2012; Faulkender et al. 2012; Öztekin and Flannery 2012; Drobetz et al. 2014). Under certain circumstances, financially constrained firms show a slow speed of adjustment to their target debt levels (López-Gracia and Sogorb-Mira 2008; Faulkender et al. 2012; Öztekin and Flannery 2012). We argue that firms accessing VC funding are financially constrained and should show a slow speed of adjustment prior to receiving VC. To the best of our knowledge, this issue has not been previously addressed in the VC literature.

The analysis is based on a sample of Spanish unlisted firms at the expansion stage that received the initial VC investment during the period from 1995 to 2007. Our analyses are also carried out on a one-by-one matched sample of firms that did not receive $\mathrm{VC}$ (the control group, hereafter). In order to analyze the dynamic behavior of leverage, we use a target adjustment model where the target debt ratio is estimated as a linear function of the determinants of leverage proposed in the literature on capital structure. Given the dynamic process found in firm leverage, the estimations are based on the Generalized Method of Moments estimator developed by Blundell and Bond (1998). The use of this technique allows us to address the autoregressive process found in the debt ratio and the fact that the explanatory variables, including the lagged value of the debt ratio, are potentially endogenous. The results show that firms that receive VC 
later adjust to their target debt ratio more slowly than other similar untreated firms, providing evidence on the existence of financial constraints on the former.

This work contributes to the literature on entrepreneurial finance in several ways. First, we provide evidence on the existence of significant financial constraints in firms that later on access $\mathrm{VC}$ funding using an alternative methodology, thus helping to explain why high-growth companies raise VC funding in a European context. Second, this is the first paper that analyzes the dynamic perspective of capital structure in unlisted companies that were later subject to a $\mathrm{VC}$ investment and provides further evidence on the role that VC firms play to fill the equity gap in unlisted firms. Third, we provide firm evidence on the difference in the dynamic behavior of leverage in companies that are later financed by VC investors when compared with that of similar companies that did not obtain VC funding. Finally, we focus on a demand side perspective of the VC market, which is frequently neglected in the literature on entrepreneurial finance.

The rest of the paper is organized as follows. In Section two we survey the theoretical literature on which we ground our hypothesis. Section three describes the sample and the methodology. The results are presented in Section four. Further robustness checks are developed in Section five. In Section six we discuss the results and conclude.

2. Financial constraints, venture capital and the capital structure adjustment process

\subsection{Financial constraints and the sensitivity of investments to cash flow}

In imperfect capital markets investment decisions are not independent from financing decisions (Modigliani and Miller 1958) due to the existence of frictions such 
as information asymmetry, agency costs and transaction costs (Jensen and Meckling 1976; Fama and Jensen 1983; Myers and Majluf 1984). These frictions affect the firms' capacity of accessing external sources of funds. As a consequence, the investment pattern of firms could be conditioned by the availability of internally generated funds (Jorgenson 1963; Hall and Jorgenson 1967). Some firms are not that much affected whereas others are heavily constrained, and basically rely on their capacity to raise funds internally to finance their investments.

The range of financial sources available is not the same for listed and unlisted firms. In addition to their internally generated funds, listed firms are able to issue shares and have easier access than unlisted firms to the debt market (Vanacker and Manigart 2010). Listed firms are required to provide periodic reliable information about their past operations and future projects, are usually larger in size and have more tangible assets to pledge as collateral. Conversely, unlisted firms are only required to publish an annual report, their size is also smaller and have fewer assets to use as collateral, and are rarely monitored by analysts or rating agencies (González and González 2012). As a result, they are most affected by information asymmetry problems when accessing external sources of funds to finance their investment projects (Berger and Udell 1998; Brav 2009), and there is substantial difference between the cost of internal and external funds in those firms (Myers and Majluf 1984; Carpenter and Petersen 2002). Hence, unlisted firms are expected to be more financially constrained than listed ones (Guariglia 2008), and may forgo their growth opportunities when internal funds are insufficient to finance investments (Gompers 1995; Michaelas et al. 1999).

Several contributions in the literature try to provide a reliable measure for the existence of financial constraints. The seminal paper by Fazzari et al. (1988) maintains that financially constrained firms show a positive dependency between investments and 
cash flow. Their article was followed by others that apply similar methodologies on different classifications of constrained and unconstrained firms (e.g., see Hubbard 1998 for a review). But this approach has raised a lot of criticism in the literature. Based on a subsample of the sample used by Fazzari et al. (1988), Kaplan and Zingales (1997) demonstrate that firms with low dividend payouts are not necessarily financially constrained. Other works support their findings (e.g., Kadapakkam et al. 1998; Cleary 1999, 2006; Almeida and Campello 2007). Kaplan and Zingales (1997, 2000) maintain that the profit-maximizing investment choices of firms do not imply a monotonic relationship between financial constraints and the dependency of investments to cash flow. A positive relationship between investments and cash flow could also be present in unconstrained firms whose managers misuse the firm's free cash flow (Jensen 1986).

The existence of mixed results could be caused by the lack of agreement among researchers on the appropriate factors to segregate more financially constrained firms from less constrained ones (Moyen 2004; Cleary et al. 2007), the fact that the variables used to define financial constraints are time invariant (Hubbard 1998), or the lack of a proper control for investment opportunities (Alti 2003). Regarding the classification issue, overinvestment should be more common in large firms whereas underinvestment should be more frequently present in smaller firms (Vogt 1994). In this line, a positive relationship between investments and cash flow signals the existence of binding financial constraints in small and young unlisted firms, which are most affected by information asymmetry problems (Carpenter and Petersen 2002). As regards the control for investment opportunities, new methodologies, such as the Euler equation approach (Bond and Meghir 1994) and the error correction model (Bond et al. 2003; Guariglia 2008), have been introduced to address the concerns raised by the original methodologies. In sum, the question on whether the existence of financial constraints is 
adequately reflected by the sensitivity of investments to cash flows is still an open area of research.

\subsection{Financial constraints and the capital structure adjustment process in unlisted} firms

A different perspective to identify the existence of financial constraints emerges from the literature about capital structure theories. Since the eighties several theories have been proposed to explain the firm's financial behavior, with the most established ones being the static trade-off and the pecking order theories. ${ }^{1}$ The former states that firms balance the advantages and disadvantages of debt in establishing their capital structure, leading to the existence of an optimum level of debt (Bradley et al. 1984). Among the advantages we should highlight tax shields (Modigliani and Miller 1963; Mackie-Mason 1990; Graham 1996) and the mitigation of agency free cash flow problems (Jensen 1986), while among the disadvantages we should recall bankruptcy costs (Kraus and Litzenberger 1973) and agency conflicts (Jensen and Meckling 1976; Myers 1977). However, due to market imperfections firms cannot achieve this optimum and therefore aim to rebalance their capital structure in an attempt to reach that level. On the contrary, the pecking order theory (Myers 1984; Myers and Majluf 1984), which is based on the existence of information asymmetries, establishes that firms follow a hierarchy in the use of funds with the aim of minimizing the financing costs. Therefore, internally generated funds are preferred to external ones and risky debt to equity. Under the pecking order theory there is not an optimum level of debt, which would then depend, in each period, on the profitability and investment opportunities of the firm.

There is ample empirical evidence on both theories in the literature (ShyamSunder and Myers 1999; Frank and Goyal 2008). These contributions are enriched by the evidence on the trade-off theory in a dynamic context, according to which leverage 
follows an adjustment process towards a target leverage ratio. While some papers find evidence of the trade-off theory (e.g., Jalilvand and Harris 1984; Fischer et al. 1989; De Miguel and Pindado 2001; Hovakimian et al. 2001; Ozkan 2001; Flannery and Rangan 2006; Lemmon et al. 2008; Huang and Ritter, 2009), others prove that the pecking order theory is able to explain better the firm's financing behavior (Shyam-Sunder and Myers 1999; Watson and Wilson 2002). Some studies also find that there are mixed effects from both theories (Fama and French 2002; Frank and Goyal 2003).

In the case of Spanish unlisted firms, there is evidence in favor of the pecking order theory (e.g., see Sánchez-Vidal and Martín-Ugedo 2005; Cardone and Cazorla 2006). However, some of these studies build on the methodology presented by ShyamSunder and Myers (1999), which is criticized by Chirinko and Singha (2000) as a valid test of the pecking order theory. In addition, the negative relationship between profitability and debt, which is found in those articles, could also be expected in a dynamic trade-off framework (Strebulaev 2007). This result is supported by González and González (2012) and López-Gracia and Sogorb-Mira (2008). They provide evidence that Spanish unlisted firms show an adjustment process to the target ratio and at the same time exhibit a negative relationship between debt and profitability and a positive relationship between debt and growth opportunities, thus providing support to both theories. This result is especially robust in the case of small unlisted firms (González and González 2012). Accordingly, as Shyam-Sunder and Myers (1999) and Chen and Zhao (2005) argue, the reversion process of the leverage ratio can also be observed even if the pecking order theory holds.

Since access to long-term debt, equity and VC markets is very limited in Europe for small firms (Guariglia 2008), the only alternative to finance growth is frequently short-term debt. Hence, the firm's ability to move towards the target debt ratio would be 
conditioned by the decision to delay rebalancing the capital structure, or by the reconsideration of undertaking the firm's investment projects (Campello et al. 2010). In this way, there is a strand in the capital structure literature that relates the speed of adjustment to the target debt ratio to the existence of financial constraints. Faulkender et al. (2012) posit that the adjustment process may differ in constrained and unconstrained firms. Dang et al. (2012) find that the speed of adjustment is faster for firms with large investments, but recognize that this finding is against the prediction that firms investing more should have a slow speed of adjustment. Regarding Spanish unlisted firms, LópezGracia and Sogorb-Mira (2008) find that SMEs are more financially constrained and show a slower speed of adjustment than large firms.

\subsection{Venture capital funding and the capital structure adjustment process}

The speed of adjustment towards a target in unlisted growing firms may be driven by the lower financial flexibility that these firms face. We argue that unlisted irms that are willing to invest to take advantage of their growth opportunities are financially constrained. They will try to access any available external source of financing. Since access to equity is very limited, especially in Europe (Guariglia 2008), they will basically resort to (short-term) debt. As a result, these firms will focus on growth rather than on adjusting their debt ratio to a target. In contrast, firms that forgo their growth opportunities, by delaying their planned investments, are able to adjust their capital structure faster. Hence, in the case on unlisted firms, which are more financially constrained than listed firms (López-Gracia and Sogorb-Mira 2008), those that are investing heavily should show a slow speed of adjustment.

In this context, we argue that firms access $\mathrm{VC}$ funding, which provides funds in the form of equity or quasi-equity to unlisted firms exhibiting outstanding growth opportunities, to re-balance their capital structure and undertake their planned 
investments. There is evidence on the higher debt levels of investee firms prior to the initial VC round. Balboa et al. (2012) find that Spanish VC-backed firms exhibit greater growth opportunities, but also greater debt ratios, than similar firms that do not have access to VC funding, before the initial VC round. Engel and Stiebale (2014) argue that firms selected by VCs may be characterized by different debt levels. Baeyens and Manigart (2006) also find that VC-backed companies have higher debt ratios than their non VC-backed counterparts before the initial investment event. This could probably lead to a reduction in their financial flexibility. Hence, the equity injection made by a VC firm would provide additional resources and rebalance the capital structure.

There is evidence on the presence of more severe financial constraints in VCbacked firms than in non VC-backed ones before the initial VC investment. This has been evidenced by the existence of a significant sensitivity of investments to cash flow in firms before receiving $\mathrm{VC}$, which is based on different methodologies and on samples from Belgium (Manigart et al. 2002), Italy and Spain (Bertoni et al. 2010, 2013), and France and the UK (Engel and Stiebale 2014). Since there is a debate on the validity of testing the existence of financial constraints by analyzing the investmentcash flow sensitivity, we will provide further evidence on this issue by focusing on an alternative methodology: the speed of adjustment towards a target debt ratio. According to Flannery and Hankins (2007), financial constraints affect the rebalancing $\operatorname{costs}^{2}$ and, therefore, the speed of adjustment towards the target. Dang et al. (2012) are the first to propose an approach that consistently estimates heterogeneous speeds of adjustments. The following hypothesis follows from this discussion:

VC-backed companies exhibit a slower speed of adjustment to the target before the initial VC investment event than similar firms that do not obtain VC funding. 


\section{Data and methodology}

\subsection{Data and sample selection}

The data used in the analysis are based on a sample of Spanish unlisted firms. The period analyzed covers initial VC investments reported from 1995 until 2007. According to the Spanish Venture Capital Association (ASCRI) and www.webcapitalriesgo.com, during this period 2,651 companies were subject to a private equity investment in Spain, including both VC and late stage deals but excluding investments in financial and real estate sectors. We were able to fully identify 2,110 companies backed with private equity, once duplicated firms (i.e. those affected by syndication and those invested by other investors in previous years) are excluded. Of these companies, 1,063 were initially funded at the seed or start-up stages, 779 were at the expansion stage and 268 belonged to the buyout and other late stages category.

We focus the analysis on companies that were at the expansion stage ${ }^{3}$ at the moment of receiving the $\mathrm{VC}$ investment for two reasons. First, we analyze the behavior of the capital structure before the VC investment event. Therefore, firms at the early stages are excluded because most of them are newly-born and there are not enough data available to analyze this period. Second, we do not include companies at late stages because we are interested in analyzing the dynamic behavior of the debt ratio in firms that are supposed to suffer most from information asymmetry problems, as stated in the previous section, which is not the case in most mature firms.

We found accounting data on $757 \mathrm{VC}$-backed companies at the expansion stage in the AMADEUS Database. ${ }^{4}$ We tried to match each VC-backed firm, one-by-one, with comparable companies not receiving VC funding. Comparable firms were randomly chosen from the AMADEUS Database, matching the sector, by means of the European Classification of Economic Activities (NACE) Rev2 code (4-digit code), the 
number of employees, the revenues, the asset volumes, the age and the location. ${ }^{5}$ All these characteristics were matched in the year before the initial VC investment (i.e., year T). We were able to identify a valid comparable firm for 605 firms that were later subject to a VC investment.

Nevertheless, the estimation process described in the following subsection requires data on at least six consecutive years to define instrumental variables efficiently (De Miguel and Pindado 2001; Gaud et al. 2005). We selected only those firms for which we have accounting data from $T$ at least until $T-5$, with $T$ being the year before the focal firm received the first VC round. Since some firms were not old enough at the time of the initial investment, this requirement reduced our sample of VC-backed companies at the expansion stage to 237 firms, representing 30.4 per cent of the population of companies at that stage and 39.2 per cent of the sample of VC-backed firms for which we were able to identify a comparable non VC-backed firm at the same stage. Our dataset also includes 237 comparable control group firms that meet the same data requirement.

We expect the impact of any survival bias to be limited because we focus on the pre-investment period, in which all VC-backed firms were obviously alive. Therefore, a positive survival bias could only marginally affect the control group firms, because the AMADEUS database deletes data on firms that disappear, albeit several years later. To mitigate this effect further, we randomly searched for comparable firms in old DVDs provided by AMADEUS when matching investments of the mid-nineties and those carried out around year 2000.

The sources of data about VC activity are ASCRI and www.webcapitalriesgo.com. The accounting data were taken from the Official Trade Registers and from the AMADEUS Database. 
Panel A of Table 1 shows mean values for sales, headcount, total assets and age for the population of VC-backed companies at the expansion stage and also for those firms finally included in the sample. With the exception of age ${ }^{6}$ no significant differences are found for all variables. Therefore, the sample can confidently be considered as representative of the population. Panel B shows the same descriptive statistics but for the sample of firms that were later subject to a VC investment and the corresponding control group included in the sample. It is important to highlight that the mean values for all variables in both groups were not statistically different in the year before the initial $\mathrm{VC}$ investment (i.e., the year of matching, T), thus showing a successful matching process based on all these characteristics.

\section{Insert Table 1 about here}

\section{2. $\quad$ Model and methodology}

The adjustment process of the debt ratio can be represented by a partial target adjustment model (De Miguel and Pindado 2001; Flannery and Rangan 2006; LópezGracia and Sogorb-Mira 2008). The form of the model shows that changes in the debt ratio $\left(D_{i t}-D_{i t-1}\right)$ partially absorb the difference between the target level and the previous debt ratio $\left(D_{i t}^{*}-D_{i t-1}\right)$ :

$$
\mathrm{D}_{\mathrm{it}}-\mathrm{D}_{\mathrm{it}-1}=\alpha\left(\mathrm{D}_{\mathrm{it}}^{*}-\mathrm{D}_{\mathrm{it}-1}\right)
$$

where $D_{i t}$ and $D_{i t-1}$ are the debt levels in the current and the previous period, respectively, $\mathrm{D}_{\mathrm{t}}^{*}$ is the company's target debt level and $\alpha^{7}$ measures the speed of adjustment. The adjustment $\operatorname{costs}^{8}$ are inversely related to $\alpha$ and can be represented as $1-\alpha$ (López-Gracia and Sogorb-Mira 2008). In this line, if $\alpha$ is zero the adjustment costs are very high and the company never adjusts its debt level to reach the target $\left(D_{i t}=D_{i t-1}\right)$. On the contrary, if $\alpha$ is equal to one there are no adjustment costs and 
the company automatically reaches its target level $\left(D_{i t}=D_{i t}^{*}\right)$. Thus, if firms follow an adjustment process to reach their target debt level, then the coefficient $\alpha$ should have a positive value between 0 and 1 . This implies a dynamic behavior where a firm adjusts its debt level towards the target according to the value of transaction costs.

According to (1), the actual level of debt is determined by:

$$
\mathrm{D}_{\mathrm{it}}=\alpha \mathrm{D}_{\mathrm{it}}^{*}+(1-\alpha) \mathrm{D}_{\mathrm{it}-1}
$$

In this equation, it should be highlighted that the target debt level is unknown and should be estimated. While in some works the target is externally determined (Jalilvand and Harris 1984; Shyam-Sunder and Myers 1999), most studies estimate this target through a regression that incorporates the determinants of the capital structure shown in the previous section of this paper as explanatory variables (e.g., see De Miguel and Pindado 2001; Flannery and Rangan 2006; López-Gracia and Sogorb-Mira 2008; González and González 2012). The latter approach is the one considered in this paper, with the target being estimated by the following model:

$D_{i t}^{*}=\mathrm{F}$ (Tangibility, Size, Profitability, Volatility, Growth opportunities,

$$
\text { Effective tax paid) }
$$

Our baseline model, represented by equation (4), incorporates equation (3) into equation (2) and adds the interaction of the lagged value of the debt ratio with a dummy variable (VC) that is equal to 1 in firms that later receive $\mathrm{VC}$, or 0 otherwise.

$$
\begin{gathered}
D_{i t}=\beta_{0}+\beta_{1} D_{i t-1}+\beta_{2} V C+\beta_{3} D_{i t-1} V C+\beta_{4} \text { Tang }_{i t}+\beta_{5} \text { Size }_{i t}+\beta_{6} \text { Prof }_{i t} \\
+\beta_{7} \text { Vol }_{i t}+\beta_{8} \text { Growth }_{i t}+\beta_{9} \text { ETR }_{i t}+\eta_{i}+\mu_{i t}
\end{gathered}
$$

The endogenous variable $\left(D_{i t}\right)$ is the ratio between long- plus short-term interest bearing debt ${ }^{9}$ and total assets for each firm and year, as in Ozkan (2001), Lemmon et al. 
(2008), Hovakimian and Li (2011, 2012), or González and González (2012). Flannery and Rangan (2006) use the same numerator but the denominator is the book value of interest bearing debt plus the market value of equity in listed firms. Our measure of the debt ratio is widely used in capital structure literature (Rajan and Zingales 1995; Hovakimian et al. 2004), and especially in the case of unlisted firms (e.g., see Cassar 2004; Chittenden et al. 1996; Michaelas et al. 1999).

In addition to the dummy $\mathrm{VC}$ and its interaction with $D_{i t-1}$, we include as independent variables the main determinants of the debt ratio. In their review, Harris and Raviv (1991) argue that there is a general consensus about the determinants that affect the capital structure of the firm, including factors such as tangible fixed assets, size-probability of default, profitability, volatility, growth opportunities, tax effects, marketing expenditures, research and development expenditures and the specificity of the product. In our empirical analysis we will consider all these characteristics except those of marketing, research and development expenditures, and the specificity of the product because of unavailability of data. The definition of the variables is as follows. Tang $_{i t}$ is the ratio between tangible fixed assets and total assets (e.g., see Rajan and Zingales 1995; Hovakimian et al. 2001; Frank and Goyal 2003; Flannery and Rangan 2006). Size $e_{i t}$ represents the size of the firm each year. It is measured by the natural logarithm of total assets, as in Titman and Wessels (1988), Hovakimian et al. (2001), Fama and French (2002) and Flannery and Rangan (2006), among others. Prof $f_{i t}$ measures the profitability for each firm and year. It is defined as the ratio between earnings before interest and taxes (EBIT) and total assets (e.g., De Miguel and Pindado 2001; Fama and French 2002; Frank and Goyal 2003; Sogorb-Mira 2005; Flannery and Rangan 2006). ol $_{i t}$ is a measure of volatility for each firm and year. Following Balboa et al. (2012), it is defined as a moving standard deviation computing the changes in 
EBIT of the current and the previous two years. Growth it $_{\text {measures growth }}$ opportunities for each firm and year. As in Michaelas et al. (1999), we use the ratio between intangible assets and total assets. $E T R_{i t}$ is the effective corporate tax paid for each firm and year. It is computed as the ratio between effective corporate tax paid and the earnings before tax, as suggested by Ozkan (2000) and López-Gracia and SogorbMira (2008). We also develop several robustness checks with alternative definitions found in the literature.

The model also includes additional control variables. First, we include an industry variable representing the median leverage per year for each group (Lemmon et al. 2008; Frank and Goyal 2009) to control for industry effects in the regression analysis, as is recommended in the literature (e.g., Scott and Martin 1975; Ferri and Jones 1979; Bowen et al. 1982; Bradley et al. 1984; Mackay and Phillips 2005). Second, all models include time year dummies in order to control for possible time effects on the leverage ratio. Finally, $\eta_{i}$ represents the specific unobservable individual effects for each company, which do not vary over time, and $\mu_{i t}$ is an error term.

The coefficient $\beta_{1}$ measures the adjustment costs of control group firms whereas $\alpha=1-\beta_{1}$ represents the speed of adjustment in those firms. In the case of the sample of firms that later receive $\mathrm{VC} \beta_{1}+\beta_{3}$ represents the adjustment costs, and the speed of adjustment is $1-\beta_{1}-\beta_{3}$. In our results we expect a positive and significant coefficient for $\beta_{3}$, which implies a significantly lower speed of adjustment of firms that later receive $\mathrm{VC}$.

The expected signs of the remaining independent variables, which are reported in the tables that show our estimates, are as follows. First, the coefficient of $\operatorname{Tang}_{\mathrm{it}}\left(\beta_{4}\right)$ should be positive and significant because tangible fixed assets preserve most of their value in case of liquidation (Wald 1999), and the empirical evidence strongly supports 
this view (e.g., see Titman and Wessels 1988; Mackie-Mason 1990; Prowse 1990; Jensen et al. 1992; Smith and Watts 1992; Hovakimian et al. 2001; Frank and Goyal 2003). Second, since the size of the company is negatively related to the probability of default (Titman and Wessels 1988; Rajan and Zingales 1995; Fama and French 2002; Frank and Goyal 2003), a positive relationship between Size ${ }_{i t}$ and $D_{i t}$ (represented by the coefficient $\beta_{5}$ ) is expected (e.g., Titman and Wessels 1988; Hovakimian et al. 2001; Frank and Goyal 2003; Rajan and Zingales 1995; Cassar 2004). Third, profitable companies are expected to have a high level of debt because one of the advantages of debt derives from the tax deductibility of interest payments (Modigliani and Miller 1963). However, more profitable companies may prefer to finance investments internally. Hence, either a positive or a negative relationship could be found, depending on the preeminence of the static trade-off theory or the pecking order theory. However, the dynamic trade-off theory also predicts a negative relationship between profitability and debt (Strebulaev 2007). Furthermore, in the case of small and medium sized firms, or privately held companies, there is firm evidence of a negative relationship between profitability and the debt ratio (Sogorb-Mira 2005; Heyman et al. 2008; López-Gracia and Sogorb-Mira 2008). Therefore, in our work we predict a negative coefficient for $\beta_{6}$. Fourth, companies with high earnings volatility are expected to raise lower debt because earnings could fall below the level of debt. Hence, we agree with Titman and Wessels (1988) that there should be a negative relationship between $\operatorname{Vol}_{i t}$ and $D_{\text {it }}$ (represented by $\beta_{7}$ ), which is widely accepted in the literature (e.g., Harris and Raviv 1991; Michaelas et al. 1999; Fama and French 2002). Fifth, according to Wald (1999) companies with high-growth opportunities have more potential to carry out future investments, and this situation could give rise to agency conflicts whereby shareholders expropriate value from bondholders. Therefore, the relationship between debt and growth opportunities 
should apparently be negative (Myers 1977; Bradley et al. 1984). However, Michaelas et al. (1999) point out that companies with high growth opportunities should use debt since the internal funds generated would not be enough to finance their growth. Thus, in our context we anticipate a positive value for the coefficient of $\operatorname{Growth}_{\mathrm{it}}\left(\beta_{8}\right)$. Finally, since firms that pay higher taxes could benefit more from tax shields, which is supported in the literature (e.g., Graham 1996; Michaelas et al. 1999), we predict a positive relationship between $\mathrm{ETR}_{\mathrm{it}}$ and $\mathrm{D}_{\text {it }}$ (represented by $\beta_{9}$ ).

We use a dynamic model to represent firm leverage behavior, which requires the use of the Generalized Method of Moments (GMM)in the estimation process. The estimations are carried out using the Blundell and Bond (1998) GMM estimator for panel data, which employs additional moment conditions based on first differences (in addition to the levels) to increase the efficiency of the estimation. The use of GMM is the adequate methodology when the data shows an autoregressive process (see the debt ratio in equation 4) and there is a potential endogeneity problem in the explanatory variables.

Two tests are carried out to check for a possible mis-specification of the model. The first is the Sargan test of over-identifying restrictions, which confirms the validity of the instruments used by checking the absence of correlation between the instruments used in the estimation and the error term. The second test examines the hypothesis of a serially uncorrelated error, since consistent estimations are only obtained if this is the case. In a dynamic model, such as the one estimated here, where differences of the variables are taken to remove the unobserved individual effects in the estimation of the model, this condition is verified if there is a lack of second order serial correlation in the first difference residuals. 


\subsection{Descriptive statistics}

In Panels $\mathrm{A}$ and $\mathrm{B}$ of Table 2 we find that companies that receive $\mathrm{VC}$ later are more indebted. Panel A shows that both the mean and median values for the total debt ratio are significantly higher for firms that receive VC later than for firms in the control group. Nevertheless, both groups are not significantly different in age ${ }^{10}$ or size, as reported in Table 1. This result is in line with Baeyens and Manigart (2006). Panel B also reports that debt ratios show a slightly increasing pattern prior to the entry of the VC investor (which could mean that the internally generated funds are insufficient to back up subsequent growth) in firms that receive VC later, whereas the ratios for control group firms are overly similar over time. A possible reason for the continuous growth found in the debt ratios for firms that later receive $\mathrm{VC}$ could be related to the fact that these firms may not be able to rebalance their capital structure very quickly, because they are in a growth process and try to use all sources of funds available.

Regarding the variables related to the target debt ratio, Panel $\mathrm{C}$ of Table 2 shows several descriptive statistics for the whole sample and the subsamples of companies that either receive $\mathrm{VC}$ or not. The significant differences on tangibility, profitability, growth opportunities and effective taxes paid between both groups could imply a different investment and financing behavior among them.

\section{Insert Table 2 about here}

Pairwise correlations among all variables are shown in Table 3. There does not seem to be any concern about the correlation among the explanatory variables. Nevertheless, in Section 4 we exclude some of the variables showing potential colinearity problems (i.e., tangible fixed assets and intangible fixed assets) and in Section 5 we perform further robustness checks by providing alternative definitions for some variables according to the literature on capital structure. 


\section{Insert Table 3 about here}

\section{Results}

In Table 4 we show the results obtained on the speed of adjustment for sample and control group firms. Model 1 reports the coefficients on our baseline model but excluding the interaction between $\mathrm{VC}$ and the lagged debt ratio (i.e., it does not disentangle among firms that received VC later and their matched peers). The adjustment cost (i.e., $\beta_{1}$ ) for all firms is 0.5011 , significant at the $1 \%$ confidence level. This implies a speed of adjustment of 0.4989. Regarding the standard determinants of the debt ratio, size, profitability and the proxy for growth opportunities have significant coefficients in all regressions whereas tangible fixed assets and volatility are significant only in some of the specifications. All of these coefficients have the predicted signs. Conversely, the determinant related to tax shields is not significant.

Since the aim of the paper is to analyze the speed of adjustment in firms that will receive $\mathrm{VC}$ prior to receiving treatment, we now focus on the coefficient of the interaction between $\mathrm{VC}$ and the lagged debt ratio (i.e., $\beta_{3}$ ). In Model 2 we report the coefficients of our baseline model. Model 3 eliminates the proxy for growth opportunities, which is intangible fixed assets over total assets, to control for potential problems with tangible fixed assets. Alternatively, Model 4 eliminates tangible fixed assets but keeps intangible fixed assets. Models 5 and 6 eliminate both the effective tax rate, which is not significant in any of the specifications and intangible fixed assets (Model 5) or tangible fixed assets (Model 6). Despite the alterations made the coefficients of the determinants used in those specifications do not show important changes, and keep their original signs and significance levels, except in the case of 
tangible fixed assets. Even volatility becomes significant at least at the $10 \%$ level with the expected negative sign.

The coefficient $\beta_{1}$ in Models 2 to 6 , which now reports the adjustment costs in control group firms, is cut by half in relation to the value estimated for all firms. This coefficient now shows values ranging from 0.2475 to 0.2782 (average $=0.2608$ ), all of them significant at the 5\% level. This implies that the average speed of adjustment in control group firms is 0.7392 . Regarding the coefficient of the interaction between VC and the lagged debt ratio, we find that it is positive and statistically significant at the $1 \%$ level in all our specifications. The coefficient is also economically significant, with the values ranging from 0.4665 to 0.4740 (average $=0.4692$ ) in Models 2 to 6 . This means that the average adjustment costs in the case of sample firms is 0.7300 (i.e., $0.2608+0.4692$ ) and the speed of adjustment is 0.2700 . In sum, we find that the difference in the speed of adjustment is statistically and economically significant among firms that will receive $\mathrm{VC}$ later and the matched control group firms, thus lending support to our hypothesis.

\section{Insert Table 4 about here}

Finally, it is interesting to jointly discuss the coefficients related to the variables that include the dummy $\operatorname{VC}\left(\beta_{2}\right.$ and $\left.\beta_{3}\right)$, and which attempt to capture heterogeneous patterns between $\mathrm{VC}$ and the control group firms that stem from differences in the degree of persistence (autoregressive coefficient, $\beta_{3}$ ) and the level (constant, $\beta_{2}$ ) of the series. The fact that $\beta_{2}$ is not significant, while $\beta_{3}$ is, is consistent with the descriptive statistics showing that VC backed firms exhibit larger debt ratios. The panel-data estimates hide the reasons underlying this sample feature, showing that these differences are exclusively due to a greater degree of persistence (as measured by the size of the autoregressive coefficient) and not caused by differences in the level. In 
other words, whereas the debt ratio of control group firms quickly reverts to a mean value and bounces randomly around it, it takes extended time for the debt ratio of VC backed firms to mean-revert to the mean, which consistently explains why the latter firms show greater unconditional means, everything else being constant. ${ }^{11}$

\section{Robustness checks and alternative explanations}

In Table 5 we show the regression results on our baseline model using other definitions found in the literature for our independent variables. First, we modify the definition of $\operatorname{Tang}_{i t}$, computing the ratio between tangible fixed assets plus inventories and total assets (e.g., Titman and Wessels 1988; Sogorb-Mira 2005). The coefficients $\beta_{1}$ and $\beta_{3}$ are 0.2547 (significant at the 5\% level) and 0.4560 (significant at the $1 \%$ level), respectively, meaning that the speed of adjustment in sample firms is 0.2893 compared to 0.7453 in control group firms. We also try an alternative definition for $\operatorname{Prof}_{i t}$ and $\operatorname{Vol}_{i t}$, using as reference the earnings before interest, taxes and depreciation rather than the EBIT (e.g., see Titman and Wessels 1988; Hovakimian et al. 2001; Ozkan 2001). When we replace both variables in our baseline model we find that the speed of adjustment of control group firms is 0.7427 whereas it is 0.2819 in the case of sample firms. The values do not change significantly when we alternatively replace the original definition of $\operatorname{Prof}_{i t}$ or $\operatorname{Vol}_{i t}$ while keeping the original definition of the other. As alternative proxy for Growt $_{i t}$ we compute revenue growth divided by revenues in the previous year (e.g., Chittenden et al. 1996; López-Gracia and Sogorb-Mira 2008). In this case, the speed of adjustment in control group firms is 0.7218 whereas it is 0.2568 in sample firms. Finally, we replace tangible fixed assets and intangible fixed assets with a variable that is the sum of tangible and intangible fixed assets. In this specification the speed of adjustment is 0.7419 in control group firms and 0.2585 in 
sample firms. In all these regressions $\beta_{1}$ and $\beta_{3}$ were significant at the $5 \%$ and at the $1 \%$ level, respectively.

\section{Insert Table 5 about here}

We also repeat the estimations of the specifications included in Table 4 using an alternative dependent variable. In order to control for the potential effect of excluding accounts payable in the numerator (Welch 2011), we define the endogenous variable following the alternative solution proposed by Rajan and Zingales (1995): long- plus short-term debt divided by total assets minus accounts payable and other non-financial liabilities. In Table 6 we show that the speed of adjustment in control group firms in the baseline model (i.e., Model 1) is 0.6499 . Regarding firms that receive $\mathrm{VC}, \beta_{3}$ is 0.4066 and the estimated speed of adjustment is 0.2433 . Considering all specifications in Table 6 , the average speed of adjustment is 0.6322 in control group firms and an average coefficient of $\beta_{3}$ of 0.4011 . Hence, the average speed of adjustment in firms that receive VC later is 0.2310 , which is broadly similar to that shown in Table 4.

\section{Insert Table 6 about here}

\section{Discussion and conclusions}

The VC literature has deeply analyzed the desired characteristics of prospective investee firms from the perspective of $\mathrm{VC}$ firms. Nevertheless, not so frequently it analyzes the real characteristics of firms that effectively obtain VC funding. VC is a financial instrument that aims to fill the equity gap in SMEs, which have a limited access to long-term funding. In this work we shed light on the financial characteristics of firms prior to receiving $\mathrm{VC}$ funding. In particular, we analyze the financial characteristics of firms that obtained $\mathrm{VC}$ at a later date to investigate whether they experience a low speed of adjustment in the years before receiving treatment. This 
approach provides evidence on whether these firms are financially constrained or not by looking at the speed of adjustment to their target debt ratios. As far as we are aware, there is no previous evidence on this issue in the literature for firms that later receive VC. The existing literature on VC just focused on evidencing financial constraints through the existence of a significant sensitivity between investments and internal cash flow in firms prior to obtaining VC. But this approach has raised extensive discussions in the literature.

We focus on a representative sample of 237 Spanish unlisted firms that received VC between 1995 and 2007 and compare the results with a one-by-one matched sample of firms that did not receive $\mathrm{VC}$ funding. In our results we find that treated firms show a significant lower speed of adjustment than their matched peers (i.e., 0.2700 in sample firms versus 0.7392 in control group firms). This result is robust to different specifications of the baseline model and to alternative definitions of the dependent and independent variables. The high speed of adjustment found in control group firms, which is close to that found in Spanish listed firms by De Miguel and Pindado (2001), could be reflecting that those firms neglect to take advantage of their growth opportunities. In this way they may adjust to the target debt level simply because they discard new investments, as the stable debt ratio reflects in our descriptive statistics. In contrast, sample firms that attract VC funding have sound growth opportunities and, simultaneously, their managers are willing to access any external source available. Therefore, their managers seem to be more concerned about funding the required investments than about adjusting the firm's debt ratio to a target level. In this way, VC becomes an alternative long-term funding source that helps investee firms balance their debt ratios. The difference found in the speed of adjustment between both groups of firms is consistent with prior studies that show that firms that later access $\mathrm{VC}$ funding 
are probably more financially constrained, thus affecting their capacity to rebalance the capital structure.

Several implications derive from the results obtained in this paper. For growing firms, those able to take advantage of growth opportunities should approach VC firms to carry out the required investments to avoid being financially constrained or, else, to be forced to abandon their growth prospects. Regarding policy makers, our findings provide further evidence on the role that VC firms play in high-growth unlisted firms, as a source of external funds that help them by reducing the dependency on the internally generated funds. We provide a financial explanation on why growing unlisted Spanish firms approach, or are attracted by, VC firms, overcoming their natural reluctance to allow an external investor to become a shareholder of the firm.

For further research it would be interesting to test whether this significant difference in the speed of adjustment to the target debt level of those two groups of companies (i.e., those that obtain or do not obtain/seek VC funding) is also present in US unlisted firms. Second, it would be important to analyze whether the high speed of adjustment found in unlisted firms that do not obtain/seek VC funding is explained by the abandonment of investment opportunities to avoid an undesirable debt level. Finally, it would be interesting to test how the speed of adjustment and the capital structure determinants change after the VC investment.

\footnotetext{
Footnotes

${ }^{1}$ Other theories based on the market situation, such as market timing (Baker and Wurgler 2002) or "Inertia" (Welch 2004), have been proposed in recent years to explain the behavior of capital structure.

${ }^{2}$ Flannery and Hankins (2007) argue that the cost of external financing sources and financial constraints affect the rebalancing costs for the debt ratio. However, we think that the former affects the availability of funds for the firm, which could be reflected in the financial constraints that the company faces.

${ }^{3}$ Companies at the expansion stage are defined as existing firms with at least one profitable line of business that seek external funding to finance the access to new markets or the introduction of new products.

${ }^{4}$ This database records information on 1,202,363 Spanish firms.
} 
${ }^{5}$ In some cases we did not find a similar firm in the same region, in terms of industry, size and age. In these cases we selected a firm from another Spanish region in which the average income per capita was similar.

${ }^{6}$ This was to be expected, since we do not consider in the sample young firms at the expansion stage because data on six consecutive years just before the initial investment are not available.

${ }^{7}$ This coefficient is assumed to be constant across companies. Nevertheless, it is probable that each firm has an individual coefficient due to its individual specific characteristics.

${ }^{8}$ As in Kayhan and Titman (2007), we simplify the specification of the adjustment costs by assuming that both leverage increasing and decreasing adjustments are symmetric. Byoun (2008) analyzed the differences in the adjustment process according to whether the firm had above-target (below-target) debt with a financial surplus (deficit).

${ }^{9}$ This category includes short-term interest bearing debt, long-term bank loans, long-term debt issued by other firms belonging to the same corporate group, obligations related to leasing contracts and other long-term debt. This latter category would include all bonds issued by the firm, including convertible bonds. However, the breakdown into these categories is not available.

${ }^{10}$ According to Berger and Udell (1998), both firm characteristics affect the sources of funds available. It is important to highlight this fact because the differences found in the financing behavior should be explained by other factors.

${ }^{11}$ Note that for a stationary $\operatorname{AR}(1)$ process $Y_{t}=c+\rho Y_{t-1}+u_{t}$, it follows that $E\left(Y_{t}\right)=\frac{c}{1-\rho}$.

Hence, the unconditional mean tends to be greater for larger values of the level c, and/or larger values of $\rho$. In the limit in which $\rho$ equals one, the process is driven by a random walk with a drift and the unconditional mean is infinite.

\section{References}

Almeida, H. and M. Campello. 2007. "Financial Constraints, Asset Tangibility, and Corporate Investments." Review of Financial Studies 20(5): 1429-1460.

Alti, A. 2003. "How Sensitive Is Investment to Cash Flow When Financing Is Frictionless?.” Journal of Finance 58(2): 707-722.

Amit, R., J. Brander, and C. Zott. 1998. "Why do Venture Capital Firms Exist? Theory and Canadian Evidence.” Journal of Business Venturing 13(6): 441-466.

Baeyens, K., and S. Manigart. 2006. "Who Gets Private Equity? The Role of Debt Capacity, Growth and Intangible Assets." WP 368, Universiteit Gent.

Baker, M., and J. Wurgler. 2002. "Market Timing and Capital Structure." Journal of Finance 57(1): 1-32.

Balboa, M., J. Martí, and A. Tresierra. 2012. "Capital Structure Determinants in Growth Firms Accessing Venture Funding." In The Oxford Handbook of Venture Capital, edited by D. Cumming, 328-353. Oxford: Canada.

Berger, A., and G. Udell. 1998. "The Economics of Small Business Finance: The Roles of Private Equity and Debt Markets in the Financial Growth Cycle." Journal of Banking and Finance 22(6-8): 613-673. 
Bertoni, F., M. G. Colombo, and A. Croce. 2010. "The Effect of Venture Capital Financing on the Sensitivity to Cash Flow of Firm's Investments." European Financial Management 16 (4): 528-551

Bessler. W., and A. Kurth. 2007. "Agency Problems and the Performance of Venturebacked IPOs in Germany: Exit Strategies, Lock-up Periods, and Bank Ownership." European Journal of Finance 13(1): 29-63.

Blundell, R. and S. Bond. 1998 "Initial Conditions and Moment Restrictions in Dynamic Panel Data Models.” Journal of Econometrics 87: 115-143.

Bond, S. and C. Meghir. 1994. "Dynamic Investment Models and the Firm's Financial Policy." Review of Economic Studies 61(2): 197-222.

Bond, S., J.A. Elston, J. Mairesse, and B. Mulkay. 2003. "Financial Factors and Investment in Belgium, France, Germany, and the United Kingdom: a Comparison Using Company Panel Data." Review of Economics and Statistics 85(1), 153-165.

Bowen, R.M., L.A. Daley, and C.C. Jr Huber. 1982. "Evidence on the Existence and Determinants of Inter-Industry Differences in Leverage." Financial Management 11: 10-20.

Bradley, M., G. Jarrell, and H. Kim. 1984. "On the Existence of an Optimal Capital Structure: Theory and Evidence.” Journal of Finance 39: 857-878.

Brav, O. 2009. "Access to Capital, Capital Structure, and the Funding of the Firm." Journal of Finance 64: 263-308.

Byoun, S. 2008. "How and When Do Firms Adjust Their Capital Structures toward Targets? ." Journal of Finance 63(6): 3069-3096.

Campello, M., J.R. Graham, and C.R. Harvey. 2010. The Real Effects of Financial Constraints: Evidence from a Financial Crisis. Journal of Financial Economics 97(3): 470-487.

Cardone, C., and L. Cazorla. 2006. "How Theory Meets Practice?: An Analysis of the Capital Structure of Spanish SMEs.” Journal of Entrepreneurial Finance and Business Ventures 11(2): 74-94.

Carpenter, R.E., and B.C. Petersen. 2002. "Is the Growth of Small Firms Constrained by Internal Finance? ." The Review of Economics and Statistics 84(2): 298-309

Cassar, G. 2004. "The Financing of Business Start-ups." Journal of Business Venturing 19: 261-283. 
Chen, L., and X. Zhao. 2005. "Profitability, Mean Reversion of Leverage Ratios, and Capital Structure Choices." WP, Michigan State University and Kent State University.

Chirinko, R.S., and A.R. Singha. 2000. "Testing Static Trade-off Against Pecking Order Models of Capital Structure: a Critical Comment.” Journal of Financial Economics 58(3): 417-425.

Chittenden, F., G. Hall, and P. Hutchinson. 1996. "Small Firm Growth, Access to Capital Markets and Financial Structure: Review of Issues and an Empirical Investigation. Small Business Economics 8(1): 59-67.

Cleary, S. 1999. "The Relationship Between Firm Investment and Financial Status." Journal of Finance 54: 673-692.

Cleary, S. 2006. "International Corporate Investment and the Relationships between Financial Constraint Measures." Journal of Banking and Finance 30(5): 15591580.

Cleary, S., P. Povel, and M. Raith. 2007. "The U-shaped Investment Curve: Theory and Evidence." Journal of Financial and Quantitative Analysis 42: 1-40.

Dang, V.A., M. Kim, and Y. Shin. 2012. “Asymmetric Capital Structure Adjustments: New Evidence from Dynamic Panel Threshold Models.” Journal of Empirical Finance 19(4): 465-482.

De Miguel, A., and J. Pindado. 2001. "Determinants of Capital Structure: New Evidence from Spanish Panel Data.” Journal of Corporate Finance 7(1): 77-99.

Drobetz, W., D.C. Schillingb, and Schröder, H. 2014. "Heterogeneity in the Speed of Adjustment across Countries and over the Business Cycle." European Financial Management, forthcoming, doi: 10.1111/eufm.12048.

Engel, D., and J. Stiebale. 2014. "Private Equity, Investment and Financial Constraints Firm-level Evidence for France and the United Kingdom." Small Business Economics 43(1): 197-212.

Fama, E., and M. Jensen. 1983. "Separation of Ownership and Control." Journal of Law and Economics 26(2): 301-325.

Fama, E., and K. French. 2002. "Testing Trade-Off and Pecking Order Predictions about Dividends and Debt." The Review of Financial Studies 15(1): 1-33.

Faulkender, M.W., M.J. Flannery, K.W. Hankins, and J.M. Smith. 2012. "Cash flows and Leverage Adjustments.” Journal of Financial Economics 103(3): 632-646. 
Fazzari, S.M., R.G. Hubbard, and B.C. Petersen. 1988. "Financing constraints and corporate investment.” Brooking Papers on Economic Activity 1: 141-206.

Ferri, M.G., and W.H. Jones. 1979. "Determinants of Financial Structure: a New Methodological Approach." Journal of Finance 34(3): 631-644.

Fischer, E., R. Heinkel, and J. Zechner. (1989). "Dynamic Capital Structure Choice: Theory and Test." Journal of Finance 44(1): 19-40.

Flannery, M.J., and K. Hankins. 2007. "A Theory of Capital Structure Adjustment Speed." WP, University. of Florida.

Flannery, M., and K. Rangan. 2006. "Partial Adjustment Toward Target Capital Structures." Journal of Financial Economics 79(3): 469-506.

Frank, M., and V. Goyal. 2003. "Testing the Pecking Order Theory of Capital Structure.” Journal of Financial Economics, 67(2), 217-248.

Frank, M., and V. Goyal. 2008. "Trade-off and Pecking Order Theories of Debt." In The Handbook of Corporate Finance: Empirical Corporate Finance edited by B.E. Eckbo, vol. 2. chapter 12.

Frank, M., and V. Goyal. 2009. "Capital Structure Decisions: Which Factors are Reliably Important.” Financial Management 38(1): 1-37.

Fried, V.H. and R.D. Hisrich. 1994. "Toward a Model of Venture Capital Investment Decision Making." Financial Management 23(3): 28-37.

Gaud, P., E. Jani, M. Hoesli, and A. Bender. 2005. "The Capital Structure of Swiss Companies: an Empirical Analysis Using Dynamic Panel Data." European Financial Management 11(1): 51-69.

Gompers, P.A. 1995. "Optimal Investment, Monitoring, and the Staging of Venture Capital." Journal of Finance 50(5): 1461-1489.

González, V.M., and F. González. 2012. "Firm Size and Capital Structure: Evidence Using Dynamic Panel Data.” Applied Economics 44(36): 4745-5219.

Graham, J. 1996. "Debt and the Marginal Tax Rate." Journal of Financial Economics 41(1): 41-73.

Guariglia, A. 2008. "Internal Financial Constraints, External Financial Constraints, and Investment Choice: Evidence from a Panel of UK firms." Journal of Banking and Finance 32(9): 1795-1809.

Hall, R.E., and D.W. Jorgenson. 1967. "Tax Policy and Investment Behavior." American Economic Review 57(3): 391-414. 
Harris, M., and A. Raviv. 1991. "The Theory of Capital Structure.” Journal of Finance 46(1): 297-355.

Heyman, D., M. Deloof, and H. Ooghe. 2008. "The Financial Structure of Privately Held Belgian Firms.” Small Business Economics 30: 301-313.

Hovakimian, A., T. Opler, and S. Titman. 2001. “The Debt-Equity Choice.” Journal of Financial and Quantitative Analysis 36(1): 1-24.

Hovakimian, A., G. Hovakimian, and H. Tehranian. 2004. "Determinants of Target Capital Structure: The Case of Dual Debt and Equity Issues." Journal of Financial Economics 71 (3): 517-40.

Hovakimian, A. and G. Li. 2011. "In Search of Conclusive Evidence: How to Test for Adjustment to Target Capital Structure.” Journal of Corporate Finance 17(1): 3344.

Hovakimian, A. and G. Li. 2012. "Is the Partial Adjustment Model a Useful Tool for Capital Structure Research.” Review of Finance 16(3): 733-54.

Huang, R., and J.R. Ritter. 2009. "Testing Theories of Capital Structure and Estimating the Speed of Adjustment." Journal of Financial and Quantitative Analysis 44 (2): $237-271$

Hubbard, G. (1998). "Capital-market Imperfections and Investment." Journal of Economic Literature 36(1): 193-225.

Jalilvand, A., and R. Harris. 1984. "Corporate Behavior in Adjusting to Capital Structure and Dividends Targets: An Econometric Study.” Journal of Finance 39(1): 127-145.

Jensen, M.C. 1986. "Agency Costs of Free Cash Flow, Corporate Finance, and Takeovers." The American Economic Review 76(2): 323-329.

Jensen, M., and W. Meckling. 1976. "Theory of the Firm: Managerial Behavior, Agency Cost and Ownership Structure.” Journal of Financial Economics 3(4): 305-360.

Jensen, G.R., D.P. Solberg, and T. Zorn. 1992. "Simultaneous Determinants of Insider Ownership, Debt and Dividend Policies.” Journal of Financial and Quantitative Analysis 27: 247-263.

Jorgenson, D.W. 1963 "Capital Theory and Investment Behavior." American Economic Review 53(2): 247-259. 
Kadapakkam, P.R., P. Kumar, and L. Riddick. 1998. “The Impact of Cash Flows and Firm Size on Investment: The International Evidence." Journal of Banking and Finance 22(3): 293-320.

Kaplan, S.N., and L. Zingales. 1997. "Do Investment-Cash Flow Sensitivities provide useful Measures of Financing Constraints?.” Quarterly Journal of Economics 112(1): 169-215.

Kaplan, S.N., and L. Zingales. 2000. "Investment-Cash Flow Sensitivities Are Not Valid Measures Of Financing Constraints." Quarterly Journal of Economics 115(2): 707-712.

Kayhan, A., and S. Titman. 2007. "Firms' Histories and Their Capital Structure." Journal of Financial Economics 83: 1-32.

Kraus, A., and R. Litzenberger. 1973. "A State-Preference Model of Optimal Financial Leverage." Journal of Finance 28(4): 911-922.

Lemmon, M.L., M. Roberts, and J. Zender. 2008. "Back to the Beginning: Persistence and the Cross-Section of Corporate Capital Structure." Journal of Finance 63(4): 1575-1608.

López-Gracia, J., and F. Sogorb-Mira. 2008. "Testing Trade-off and Pecking Order Theories Financing SMEs.” Small Business Economics 31(2): 117-136.

MacKie-Mason, J. 1990. "Do Taxes Affect Corporate Financing Decisions?.” Journal of Finance 45(5): 1471-1493.

Mackay, P., and G.M. Phillips. 2005. "How Does Industry Affect Firm Financial Structure?." The Review of Financial Studies 18(4): 1433-1466.

Manigart, S., K. Baeyens, and I. Verschueren. 2002. "Financing and Investment Interdependencies in Unquoted Belgian Companies: the Role of Venture Capital." Vlerick WP 29, National Bank of Belgium.

Michaelas, N., F. Chittenden, and P. Poutziouris. 1999. "Financial Policy and Capital Structure Choice in U.K. SMEs: Empirical Evidence from Company Panel Data." Small Business Economics 12(2): 113-130.

Modigliani, F., and M. Miller. 1958. "The Cost of Capital, Corporation Finance and the Theory of Investment.” American Economic Review 48(3): 261-297.

Modigliani, F., and M. Miller. 1963. "Corporate Income Taxes and the Cost of Capital: A Correction." The American Economic Review 53(3): 433-443.

Moyen, N. 2004. "Investment-cash Flow Sensitivities: Constrained versus Unconstrained Firms.” Journal of Finance 59(5): 2061-2092. 
Myers, S. 1977. "Determinants of Corporate Borrowing." Journal of Financial Economics 5(2): 147-175.

Myers, S. 1984. “The Capital Structure Puzzle.” Journal of Finance 39(3): 575-592.

Myers, S., and N. Majluf. 1984. "Corporate Financing and Investment Decisions when Firms have Information Investors do not have." Journal of Financial Economics 13(2): 187-221.

Ozkan, A. 2000. "An Empirical Analysis of Corporate Debt Maturity Structure." European Financial Management 6(2): 197-212.

Ozkan, A. 2001. "Determinants of Capital Structure and Adjustment to Long Run Target: Evidence from UK Company Panel Data.” Journal of Business Finance and Accounting 28(1-2): 175-198.

Öztekin, Ö., and M.J. Flannery. 2012. "Institutional Determinants of Capital Structure Adjustment Speeds”. Journal of Financial Economics 103: 88-112.

Prowse, S. 1990. "Institutional Investment Patterns and Corporate Financial Behavior in the US and Japan." Journal of Financial Economics 27: 43-66.

Rajan, R., and L. Zingales. 1995. "What do we Know about Capital Structure? Some Evidence from International Data.” Journal of Finance 50(5): 1421-1460

Reid, .C., N.G. Terry, and J.A. Smith. 2010. "Risk Management in Venture Capital Investor-Investee Relations.” European Journal of Finance 3(1): 27-47.

Sánchez-Vidal, J., and J. Martín-Ugedo. 2005. "Financing Preferences of Spanish Firms: Evidence on the Pecking Order Theory. Review of Quantitative Finance and Accounting 25(4): 341-355.

Sahlman, W.A. 1990. "The Structure and Governance of Venture Capital Organizations.” Journal of Financial Economics 27(2): 473-521.

Scott, D.F.Jr., and J.D. Martin. 1975. "Industry Influence on Financial Structure." Financial Management 4(1): 67-73.

Shyam-Sunder, L., and S. Myers. 1999. "Testing Static Trade-off against Pecking Order Models of Capital Structure.” Journal of Financial Economics 51(2): 219244.

Smith, C. W. Jr., and R. L. Watts. 1992. "The Investment Opportunity Set and Corporate Financing, Dividend and Compensation Policies." Journal of Financial Economics 32(3): 263-292. 
Sogorb-Mira, F. 2005. "How SME Uniqueness Affects Capital Structure: Evidence From a 1994-1998 Spanish Data Panel.” Small Business Economics 25(5): 447457.

Strebulaev, I.A. 2007. "Do Tests of Capital Structure Theory Mean What They Say?." Journal of Finance 62(4): 1747-1787.

Titman, S., and R. Wessels. 1988. "The Determinants of Capital Structure Choice." Journal of Finance 43(1): 1-19.

Tyebjee, T.T., and A.V. Bruno. 1984. "A Model of Venture Capitalist Investment Activity." Management Science 30(9): 1051-1066.

Vanacker, T.R., and S. Manigart. 2010. "Pecking Order and Debt Capacity Considerations for High-growth Companies Seeking Financing.” Small Business Economics 35(1): 53-69.

Vogt, S.C. 1994. "The Cash Flow/Investment Relationship: Evidence from U.S. Manufacturing Firms." Financial Management 23(2): 3-20.

Wald, J. 1999. "How Firm Characteristics Affect Capital Structure: an International Comparison." Journal of Financial Research 22: 161-187.

Watson, R., and N. Wilson. 2002. "Small and Medium Size Enterprise Financing: A Note on Some of the Empirical Implications of a Pecking Order." Journal of Business Finance and Accounting 29(3-4): 557-578.

Welch, I. 2004. “Capital Structure and Stock Returns.” Journal of Political Economy 112(1): 106-131.

Welch, I. 2011. "Two Common Problems in Capital Structure Research: The FinancialDebt-to-Asset Ratio and Issuing Activity versus Leverage Changes." International Review of Finance 11 (1): 1-17. 
Table 1. Mean of sales, headcount, total assets and age in the sample

\begin{tabular}{|c|c|c|c|c|c|}
\hline Group & Number & Sales* & Employees & Assets* & $\operatorname{Age}^{* *}$ \\
\hline \multicolumn{6}{|c|}{ Panel A-Comparison firms later receive VC: population vs. sample } \\
\hline Population & 757 & 27,195 & 180 & 23,867 & 12.593 \\
\hline \multirow[t]{2}{*}{ Sample } & 237 & 25,461 & 185 & 22,865 & 18.515 \\
\hline & p-value & 0.7873 & 0.9132 & 0.8199 & 0.0000 \\
\hline \multicolumn{6}{|c|}{ Panel B-Comparison sample: later receive VC vs. Control Group } \\
\hline Later receive $\mathrm{VC}$ & 237 & 25,461 & 185 & 22,865 & 18.515 \\
\hline \multirow[t]{2}{*}{ Control Group } & 237 & 22,955 & 153 & 17,382 & 17.404 \\
\hline & p-value & 0.6501 & 0.5191 & 0.1969 & 0.2951 \\
\hline
\end{tabular}

Data refers to the year before the VC investment event.

*Thousand constant 2005 Euros.

** In years.

Source: Amadeus Database. 
Table 2. Descriptive statistics

Panel A. Debt ratio: Whole period before the initial VC investment (from T-5 to T)

\begin{tabular}{|c|c|c|c|c|c|c|c|}
\hline & Obs. & \# Firms & Mean & Median & Std. Dev. & Min & Max \\
\hline All firms & 2,934 & 474 & 0.2115 & 0.1737 & 0.1870 & 0.0000 & 0.9087 \\
\hline Later receive $\mathrm{VC}$ & 1,489 & 237 & 0.2492 & 0.2378 & 0.1824 & 0.0000 & 0.8568 \\
\hline Control Group & 1,445 & 237 & 0.1727 & 0.1129 & 0.1837 & 0.0000 & 0.9087 \\
\hline & & & 0.0000 & 0.0000 & & & \\
\hline
\end{tabular}

Panel B. Debt ratio: Year by year evolution prior to the initial VC investment (from T-5 to T)

$\begin{array}{llllll}\text { T } & \text { T-1 } & \text { T-2 } & \text { T-3 } & \text { T-4 } & \text { T-5 }\end{array}$

\begin{tabular}{|c|c|c|c|c|c|c|c|}
\hline \multicolumn{8}{|l|}{ Mean values } \\
\hline Later receive $\mathrm{VC}$ & & 0.2823 & 0.2654 & 0.2522 & 0.2409 & 0.2352 & 0.2252 \\
\hline \multirow[t]{2}{*}{ Control Group } & & 0.1702 & 0.1753 & 0.1778 & 0.1708 & 0.1695 & 0.1620 \\
\hline & p-value & 0.0000 & 0.0000 & 0.0000 & 0.0000 & 0.0002 & 0.0024 \\
\hline \multicolumn{8}{|l|}{ Median values } \\
\hline$\overline{\text { Later receive } \mathrm{VC}}$ & & 0.2862 & 0.2542 & 0.2421 & 0.2176 & 0.2143 & 0.2186 \\
\hline \multirow[t]{2}{*}{ Control Group } & & 0.1191 & 0.1183 & 0.1154 & 0.1143 & 0.1085 & 0.0886 \\
\hline & $\mathrm{p}$-value & 0.0000 & 0.0000 & 0.0000 & 0.0000 & 0.0000 & 0.0000 \\
\hline
\end{tabular}

Panel C. Independent variables: Whole period before the initial VC investment (from T-5 to T)

\begin{tabular}{llcccccr}
\hline Variable & \multicolumn{1}{c}{ Group } & Obs. & Mean & Median & Std. Dev. & Min & \multicolumn{1}{c}{ Max } \\
\hline \multirow{2}{*}{ Tang } & All firms & 2,934 & 0.1917 & 0.1350 & 0.1902 & 0.0000 & 0.9240 \\
& Later receive VC & 1,489 & $0.2507^{* * *}$ & $0.2110^{* * *}$ & 0.1907 & 0.0000 & 0.9240 \\
\multirow{4}{*}{ Size } & Control Group & 1,445 & 0.1309 & 0.0511 & 0.1694 & 0.0000 & 0.9220 \\
& All firms & 2,934 & 15.4525 & 15.4065 & 1.4717 & 8.8537 & 20.2716 \\
& Later receive VC & 1,489 & $15.5108^{* *}$ & $15.4512^{*}$ & 1.4443 & 8.8537 & 20.2716 \\
\multirow{4}{*}{ Prof } & Control Group & 1,445 & 15.3924 & 15.3205 & 1.4975 & 11.4076 & 19.6797 \\
& All firms & 2,934 & 0.0671 & 0.0609 & 0.1024 & -0.9536 & 0.7111 \\
& Later receive VC & 1,489 & $0.0583^{* * *}$ & $0.0568^{* * *}$ & 0.1028 & -0.9536 & 0.6168 \\
Vol & Control Group & 1,445 & 0.0761 & 0.0653 & 0.1012 & -0.6222 & 0.7111 \\
& All firms & 2,934 & 2.1030 & 0.4232 & 11.5574 & 0.0001 & 215.4583 \\
& Later receive VC & 1,489 & 2.3706 & 0.4150 & 12.4227 & 0.0002 & 207.3391 \\
\multirow{4}{*}{ GO } & Control Group & 1,445 & 1.8272 & 0.4258 & 10.5892 & 0.0001 & 215.4583 \\
& All firms & 2,934 & 0.0606 & 0.0161 & 0.1101 & 0.0000 & 0.9886 \\
& Later receive VC & 1,489 & $0.0642^{* * *}$ & $0.0233^{* * *}$ & 0.1020 & 0.0000 & 0.8421 \\
\multirow{2}{*}{ ETR } & Control Group & 1,445 & 0.0569 & 0.0108 & 0.1178 & 0.0000 & 0.9885 \\
& All firms & 2,934 & 0.2467 & 0.2984 & 0.1902 & 0.0000 & 1.0000 \\
& Later receive VC & 1,489 & $0.2300^{* * *}$ & $0.2700^{* * *}$ & 0.1962 & 0.0000 & 1.0000 \\
& Control Group & 1,445 & 0.2639 & 0.3080 & 0.1823 & 0.0000 & 1.0000 \\
\hline
\end{tabular}

Data refers to all years in the sample before the initial VC investment event (from T-5 to T). $\mathrm{T}$ is the year before the firm received the first VC round, and the year of matching.

Debt Ratio: ratio between long- plus short-term debt and total assets.

Independent variables: Tang: Ratio between tangible fixed assets and total assets. Size: Natural logarithm of total assets; Prof: Ratio between EBIT and total assets. Vol: Moving standard deviation of the change in EBIT, computing the current and the two previous years. GO: Ratio between intangible assets and total assets. ETR: Ratio between the effective corporate tax paid and the earnings before tax.

Differences in means (t- test) and medians (chi-squared test statistic) are reported: firms that later receive VC vs. firms that not receive. Significance at levels $* * * 1 \%, * * 5 \%, * 10 \%$. 
Table 3. Correlation matrix

\begin{tabular}{lrrrrrrr}
\hline & Tang & Size & Prof & Vol & GO & ETR & NDTS \\
\hline Tang & 1.0000 & & & & & & \\
Size & $\mathbf{0 . 1 1 0 2}$ & 1.0000 & & & & & \\
Prof & -0.0578 & -0.0491 & 1.0000 & & & & \\
Vol & 0.0037 & -0.0103 & $\mathbf{- 0 . 1 2 2 4}$ & 1.0000 & & & \\
GO & $\mathbf{- 0 . 1 2 8 6}$ & -0.0123 & $\mathbf{- 0 . 1 3 3 9}$ & $\mathbf{0 . 1 1 0 5}$ & 1.0000 & & \\
ETR & $\mathbf{- 0 . 0 6 1 1}$ & -0.0118 & $\mathbf{0 . 2 1 5 9}$ & -0.0506 & $\mathbf{- 0 . 0 7 7 8}$ & 1.0000 & \\
\hline
\end{tabular}

Definition of variables. Tang: Ratio between tangible fixed assets and total assets. Size: Natural logarithm of total assets. Prof: Ratio between EBIT and total assets. Vol: Moving standard deviation of the change in EBIT, computing the current and the previous two years. GO: Ratio between intangible assets and total assets. ETR: Ratio between the effective corporate tax paid and the earnings before tax.

Significant values at the 5 percent level in bold. 
Table 4. Regression results: total debt ratio

\begin{tabular}{|c|c|c|c|c|c|c|c|c|}
\hline Var. & Sign & Model 1 & Model 2 & Model 3 & \multicolumn{2}{|l|}{ Model 4} & Model 5 & Model 6 \\
\hline \multirow[t]{2}{*}{$\operatorname{Debt}_{\mathrm{t}-1}$} & + & $0.5011^{* * *}$ & $0.2511^{* *}$ & $0.2755^{* *}$ & 0.2475 & ** & $0.2782^{* *}$ & $0.2518^{*}$ \\
\hline & & $(0.0823)$ & $(0.1272)$ & $(0.1305)$ & $(0.1266)$ & & $(0.1325)$ & $(0.1293)$ \\
\hline \multirow[t]{2}{*}{$\mathrm{VC}$} & & -0.0145 & -0.0959 & -0.0978 & -0.0808 & & $-0.1017^{*}$ & -0.0842 \\
\hline & & $(0.0776)$ & $(0.0603)$ & $(0.0603)$ & $(0.0573)$ & & $(0.0607)$ & $(0.0577)$ \\
\hline \multirow{2}{*}{$\operatorname{Debt}_{\mathrm{t}-1} * \mathrm{VC}$} & + & & $0.4700^{* * * *}$ & $0.4666^{* * *}$ & 0.4665 & $* * *$ & $0.4740^{* * *}$ & $0.4690^{* * * *}$ \\
\hline & & & $(0.1712)$ & $(0.1692)$ & $(0.1687)$ & & $(0.1724)$ & $(0.1718)$ \\
\hline \multirow[t]{2}{*}{ Tang } & + & $0.1161^{* *}$ & 0.0842 & 0.0778 & & & 0.0764 & \\
\hline & & $(0.0507)$ & $(0.0515)$ & $(0.0506)$ & & & $(0.0504)$ & \\
\hline \multirow[t]{2}{*}{ Size } & + & $0.0563^{\text {**** }}$ & $0.0504^{* * * *}$ & $0.0512^{* * *}$ & 0.0510 & $* * *$ & $0.0511^{* * *}$ & $0.0512^{* * *}$ \\
\hline & & $(0.0096)$ & $(0.0090)$ & $(0.0089)$ & $(0.0089)$ & & $(0.0088)$ & $(0.0089)$ \\
\hline \multirow[t]{2}{*}{ Prof } & - & $-0.1881^{\text {*** }}$ & $-0.1789^{* * * *}$ & $-0.1713^{* * *}$ & -0.1856 & $* * *$ & $-0.1696^{* * *}$ & $-0.1847^{* * *}$ \\
\hline & & $(0.0484)$ & $(0.0501)$ & $(0.0529)$ & $(0.0501)$ & & $(0.0528)$ & $(0.0500)$ \\
\hline \multirow[t]{2}{*}{ Vol } & - & -0.0008 & $-0.0008^{*}$ & $-0.0006^{*}$ & -0.0008 & ** & $-0.0006^{*}$ & $-0.0008^{* *}$ \\
\hline & & $(0.0006)$ & $(0.0004)$ & $(0.0004)$ & $(0.0004)$ & & $(0.0004)$ & $(0.0004)$ \\
\hline \multirow[t]{2}{*}{$\mathrm{GO}$} & + & $0.2848^{* * * *}$ & $0.2492^{* * * *}$ & & 0.2429 & $* * *$ & & $0.2406^{* * *}$ \\
\hline & & $(0.0758)$ & $(0.0635)$ & & $(0.0630)$ & & & $(0.0621)$ \\
\hline \multirow[t]{2}{*}{ ETR } & + & 0.0009 & -0.0033 & -0.0023 & -0.0042 & & & \\
\hline & & $(0.0168)$ & $(0.0175)$ & $(0.0178)$ & $(0.0177)$ & & & \\
\hline \multirow{2}{*}{ Industry } & & 0.0418 & 0.0958 & 0.0685 & 0.1053 & & 0.0609 & 0.0971 \\
\hline & & $(0.1063)$ & $(0.1037)$ & $(0.0979)$ & $(0.1028)$ & & $(0.0977)$ & $(0.1028)$ \\
\hline \multirow{3}{*}{$\begin{array}{c}\text { Time } \\
\text { dummies } \\
\text { Constant }\end{array}$} & & yes & yes & yes & yes & & yes & yes \\
\hline & & $-0.7600^{* * *}$ & $-0.6430^{* * *}$ & $-0.6367^{* * *}$ & -0.6429 & $* * *$ & $-0.6337^{* * *}$ & $-0.6434^{* * *}$ \\
\hline & & $(0.1451)$ & $(0.1355)$ & $(0.1319)$ & $(0.1340)$ & & $(0.1316)$ & $(0.1329)$ \\
\hline \multirow{2}{*}{$\begin{array}{l}\text { Observations } \\
\text { \# Firms }\end{array}$} & & 2,934 & 2,934 & 2,934 & 2,934 & & 2,934 & 2,934 \\
\hline & & 474 & 474 & 474 & 474 & & 474 & 474 \\
\hline \multirow{2}{*}{$\begin{array}{c}\mathrm{m}_{1} \\
\mathrm{p} \text {-value }\end{array}$} & & -4.4734 & -4.1897 & -4.3669 & -4.1743 & & -4.3536 & -4.1696 \\
\hline & & $(0.0000)$ & $(0.0000)$ & $(0.0000)$ & $(0.0000)$ & & $(0.0000)$ & $(0.0000)$ \\
\hline \multicolumn{2}{|l|}{$\mathrm{m}_{2}$} & 0.9241 & 0.8998 & 0.9420 & 0.8639 & & 0.9364 & 0.8558 \\
\hline \multicolumn{2}{|l|}{$\mathrm{p}$-value } & $(0.3555)$ & $(0.3683)$ & $(0.3462)$ & $(0.3876)$ & & $(0.3490)$ & $(0.3921)$ \\
\hline \multirow{2}{*}{\multicolumn{2}{|c|}{ Sargan }} & 67.9192 & 106.8764 & 100.2933 & 105.7032 & & 100.4919 & 106.2630 \\
\hline & & $(0.1133)$ & $(0.1541)$ & $(0.2843)$ & $(0.1735)$ & & $(0.2797)$ & $(0.1640)$ \\
\hline
\end{tabular}

Regressions are estimated using the Blundell and Bond GMM estimator for panel data.

Period analyzed: $\mathrm{t}$ varies from T-5 until T, with $\mathrm{T}$ being the year before the initial VC round.

Dependent variable: Ratio between long- plus short-term debt and total assets. Independent Variables. Tang: Ratio between tangible fixed assets and total assets. Size: Natural logarithm of total assets. Prof: Ratio between EBIT and total assets. Vol: Moving standard deviation of the change in EBIT, computing the current and the two previous years. GO: Ratio between intangible assets and total assets. ETR: Ratio between the effective corporate tax paid and the earnings before tax. Industry: median leverage per year and industry. $\mathrm{m} 1$ and $\mathrm{m} 2$ : first and second order serial correlation test, respectively. Sargan: Sargan test of the overidentifying restrictions. Robust standard errors in brackets. Sign: shows the predicted sign of the variable.

Significance at levels $* * * 1 \%, * * 5 \%, * 10 \%$. 
Table 5. Robustness checks: alternative independent variables

\begin{tabular}{|c|c|c|c|c|c|c|c|}
\hline Var. & Sign & Model 7 & Model 8 & Model 9 & $\begin{array}{r}\text { Model } \\
10\end{array}$ & Model 11 & $\begin{array}{r}\text { Model } \\
12\end{array}$ \\
\hline \multirow[t]{2}{*}{ Debt $_{t-1}$} & + & $0.2547^{* *}$ & $0.2573^{* *}$ & $0.2544^{* * *}$ & $0.2545^{* * *}$ & $0.2782^{* *}$ & $0.2581^{* *}$ \\
\hline & & $(0.1256)$ & $(0.1278)$ & $(0.1254)$ & $(0.1298)$ & $(0.1291)$ & $(0.1310)$ \\
\hline \multirow[t]{2}{*}{$\mathrm{VC}$} & & -0.0860 & -0.0918 & -0.0942 & -0.0925 & -0.0988 & -0.1083 \\
\hline & & $(0.0585)$ & $(0.0610)$ & $(0.0597)$ & $(0.0615)$ & $(0.0609)$ & $(0.0662)$ \\
\hline \multirow{2}{*}{$\operatorname{Debt}_{\mathrm{t}-1} * \mathrm{VC}$} & + & $0.4560^{* * * *}$ & $0.4608^{* * *}$ & $0.4680^{* * * *}$ & $0.4620^{* * *}$ & $0.4649^{* * *}$ & $0.4834^{* * *}$ \\
\hline & & $(0.1683)$ & $(0.1717)$ & $(0.1693)$ & $(0.1737)$ & $(0.1682)$ & $(0.1724)$ \\
\hline \multirow[t]{2}{*}{ Tang } & + & & $0.0993^{*}$ & $0.0900^{*}$ & $0.0932^{*}$ & 0.0719 & \\
\hline & & & $(0.0517)$ & $(0.0511)$ & $(0.0523)$ & $(0.0508)$ & \\
\hline Tang2 & + & $\begin{array}{r}0.0261 \\
(0.0312)\end{array}$ & & & & & \\
\hline Fixed & + & & & & & & $\begin{array}{c}0.1372^{* * *} \\
(0.0435)\end{array}$ \\
\hline \multirow[t]{2}{*}{ Size } & + & $0.0517^{* * *}$ & $0.0521^{* * *}$ & $0.0477^{* * * *}$ & $0.0548^{* * *}$ & $0.0521^{* * *}$ & $0.0520^{* * *}$ \\
\hline & & $(0.0090)$ & $(0.0106)$ & (0.0089) & (0.0109) & $(0.0087)$ & $(0.0106)$ \\
\hline \multirow[t]{2}{*}{ Prof } & - & $-0.1826^{* * * *}$ & & & $-0.1810^{* * * *}$ & $-0.1674^{* * *}$ & $-0.1809^{* * *}$ \\
\hline & & $(0.0484)$ & & & $(0.0504)$ & $(0.0531)$ & $(0.0519)$ \\
\hline \multirow[t]{2}{*}{ Prof2 } & - & & $-0.1841^{* * *}$ & $-0.1814^{* * *}$ & & & \\
\hline & & & $(0.0474)$ & $(0.0475)$ & & & \\
\hline \multirow[t]{2}{*}{ Vol } & - & $-0.0008^{* *}$ & & $-0.0008^{*}$ & & $-0.0006^{*}$ & \\
\hline & & $(0.0004)$ & & (0.0004) & & $(0.0004)$ & \\
\hline \multirow[t]{2}{*}{ Vol2 } & - & & -0.0002 & & -0.0002 & & -0.0002 \\
\hline & & & $(0.0007)$ & & $(0.0007)$ & & $(0.0007)$ \\
\hline \multirow[t]{2}{*}{ GO } & + & $0.2475^{* * *}$ & $0.2548^{* * *}$ & $0.2542^{* * *}$ & $0.2501^{* * *}$ & & \\
\hline & & $(0.0630)$ & $(0.0678)$ & $(0.0633)$ & $(0.0678)$ & & \\
\hline \multirow[t]{2}{*}{$\mathrm{GO} 2$} & + & & & & & -0.0058 & \\
\hline & & & & & & $(0.0037)$ & \\
\hline \multirow{2}{*}{ ETR } & + & -0.0037 & -0.0072 & -0.0048 & -0.0058 & -0.0027 & -0.0036 \\
\hline & & $(0.0176)$ & $(0.0178)$ & $(0.0175)$ & $(0.0178)$ & (0.0177) & $(0.0182)$ \\
\hline \multirow[t]{2}{*}{ Industry } & & 0.1047 & 0.0789 & 0.0926 & 0.0824 & 0.0702 & 0.0746 \\
\hline & & $(0.1028)$ & $(0.1037)$ & $(0.1044)$ & $(0.1032)$ & $(0.0987)$ & $(0.1000)$ \\
\hline \multirow{3}{*}{$\begin{array}{c}\text { Time } \\
\text { dummies } \\
\text { Constant }\end{array}$} & & yes & yes & yes & yes & yes & yes \\
\hline & & $-0.6611^{* * *}$ & $-0.6624^{* * * *}$ & $-0.5972^{* * * *}$ & $-0.7079^{* * *}$ & $-0.6505^{* * *}$ & $-0.6670^{* * *}$ \\
\hline & & $(0.1337)$ & $(0.1568)$ & $(0.1349)$ & $(0.1607)$ & $(0.1293)$ & $(0.1557)$ \\
\hline \multirow{2}{*}{$\begin{array}{l}\text { Observations } \\
\text { \# Firms }\end{array}$} & & 2,934 & 2,934 & 2,934 & 2,934 & 2,934 & 2,934 \\
\hline & & 474 & 474 & 474 & 474 & 474 & 474 \\
\hline \multirow{2}{*}{$\begin{array}{l}\mathrm{m}_{1} \\
\text {-value }\end{array}$} & & -4.4644 & -4.2042 & -4.1822 & -4.2109 & -4.3397 & -4.2635 \\
\hline & & $(0.0000)$ & $(0.0000)$ & $(0.0000)$ & $(0.0000)$ & $(0.0000)$ & $(0.0000)$ \\
\hline \multicolumn{2}{|l|}{$\mathrm{m}_{2}$} & 0.8965 & 0.9220 & 0.9176 & 0.9055 & 0.9525 & 0.9014 \\
\hline \multicolumn{2}{|l|}{ p-value } & $(0.3700)$ & $(0.3565)$ & $(0.3588)$ & $(0.3652)$ & $(0.3408)$ & $(0.3674)$ \\
\hline \multicolumn{2}{|l|}{ Sargan } & 69.9028 & 109.6552 & 107.5328 & 109.4218 & 100.3204 & 104.0836 \\
\hline \multicolumn{2}{|l|}{$\mathrm{p}$-value } & $(0.0850)$ & $(0.1144)$ & $(0.1439)$ & (0.1174) & $(0.2837)$ & $(0.2030)$ \\
\hline
\end{tabular}

Regressions are estimated using the Blundell and Bond GMM estimator for panel data.

Period analyzed: $\mathrm{t}$ varies from T-5 until T, with $\mathrm{T}$ being the year before the initial VC round.

Dependent variable: Ratio between long plus short term debt and total assets. Independent Variables. Tang: Ratio between tangible fixed assets and total assets. Tang2: Ratio between tangible fixed assets plus inventories and total assets. Fixed: Ratio between fixed assets and total assets. Size: Natural logarithm of total assets. Prof: Ratio between EBIT and total assets. Prof2: Ratio between EBITDA and total assets. Vol: Moving standard deviation of the change in EBIT, computing the current and the two previous years; Vol2: Same procedure using EBITDA. GO: Ratio between intangible assets and total assets. GO2: Ratio between revenue growth and revenues in the previous year. ETR: Ratio between the effective corporate tax paid and the earnings before tax. Industry: median leverage per year and industry group. $\mathrm{m} 1$ and $\mathrm{m} 2$ : first and second order serial correlation test, respectively. Sargan: Sargan test of the overidentifying restrictions. Robust standard errors in brackets. Sign: shows the predicted sign of the variable.

Significance at levels $* * * 1 \%, * * 5 \%, * 10 \%$. 
Table 6. Robustness checks: adjusted total debt ratio as dependent variable

\begin{tabular}{|c|c|c|c|c|c|c|c|}
\hline Var. & Sign & Model 1 & Model 2 & Model 3 & Model 4 & Model 5 & Model 6 \\
\hline \multirow[t]{2}{*}{$\operatorname{Debt}_{\mathrm{t}-1}$} & \multirow[t]{2}{*}{+} & $0.5631^{\text {*** }}$ & $0.3501^{* *}$ & $0.3889^{* *}$ & $0.3440^{* *}$ & $0.4016^{* *}$ & $0.3545^{* *}$ \\
\hline & & $(0.0717)$ & $(0.1619)$ & $(0.1650)$ & $(0.1616)$ & $(0.1651)$ & $(0.1624)$ \\
\hline \multirow[t]{2}{*}{$\mathrm{VC}$} & & 0.0643 & -0.0948 & 0.0900 & -0.0875 & -0.0902 & -0.0896 \\
\hline & & $(0.1001)$ & $(0.0810)$ & $(0.0828)$ & $(0.0807)$ & $(0.0827)$ & $(0.0813)$ \\
\hline \multirow{2}{*}{$\mathrm{Debt}_{\mathrm{t}-1} * \mathrm{VC}$} & + & & $0.4066^{*}$ & $0.3890^{*}$ & $0.4136^{*}$ & $0.3862^{*}$ & $0.4103^{*}$ \\
\hline & & & $(0.2207)$ & $(0.2208)$ & $(0.2197)$ & $(0.2209)$ & $(0.2217)$ \\
\hline \multirow[t]{2}{*}{ Tang } & + & 0.0555 & 0.0649 & 0.0484 & & 0.0446 & \\
\hline & & $(0.0605)$ & $(0.0596)$ & $(0.0597)$ & & $(0.0612)$ & \\
\hline \multirow[t]{2}{*}{ Size } & + & $0.0661^{* * * *}$ & $0.0575^{* * * *}$ & $0.0585^{* * *}$ & $0.0575^{* * *}$ & $0.0596^{* * * *}$ & $0.0585^{* * *}$ \\
\hline & & $(0.0164)$ & $(0.0135)$ & $(0.0136)$ & $(0.0136)$ & $(0.0138)$ & $(0.0136)$ \\
\hline \multirow[t]{2}{*}{ Prof } & - & $-0.2193^{* * *}$ & $-0.1623^{* * * *}$ & $-0.1597^{* * *}$ & $-0.1654^{* * * *}$ & $-0.1568^{* *}$ & $-0.1647^{* * *}$ \\
\hline & & $(0.0604)$ & $(0.0594)$ & $(0.0622)$ & $(0.0585)$ & $(0.0621)$ & $(0.0583)$ \\
\hline \multirow[t]{2}{*}{ Vol } & - & -0.0007 & $-0.0008^{*}$ & -0.0007 & $-0.0008^{*}$ & -0.0006 & $-0.0008^{*}$ \\
\hline & & $(0.0006)$ & $(0.0005)$ & $(0.0004)$ & $(0.0005)$ & $(0.0004)$ & $(0.0005)$ \\
\hline \multirow[t]{2}{*}{$\mathrm{GO}$} & + & $0.2464^{* * * *}$ & $0.2687^{* * * *}$ & & $0.2660^{* * * *}$ & & $0.2631^{* * * *}$ \\
\hline & & $(0.0761)$ & $(0.0694)$ & & $(0.0693)$ & & $(0.0685)$ \\
\hline \multirow[t]{2}{*}{ ETR } & + & -0.0006 & -0.0085 & -0.0040 & -0.0092 & & \\
\hline & & $(0.0210)$ & $(0.0220)$ & $(0.0222)$ & $(0.0218)$ & & \\
\hline \multirow[t]{2}{*}{ Industry } & & $0.1692^{*}$ & $0.1651^{*}$ & $0.1772^{*}$ & 0.1597 & $0.2098^{*}$ & 0.1816 \\
\hline & & (0.0984) & (0.0989) & $(0.1020)$ & $(0.0983)$ & $(0.1237)$ & $(0.1133)$ \\
\hline \multirow{3}{*}{$\begin{array}{c}\text { Time } \\
\text { dummies } \\
\text { Constant }\end{array}$} & & yes & yes & yes & yes & yes & yes \\
\hline & & $-1.0245^{\text {**** }}$ & $-0.8277^{* * *}$ & $-0.8451^{* * *}$ & $-0.8131^{* * *}$ & $-0.8905^{* * *}$ & $-0.8478^{* * *}$ \\
\hline & & $(0.2576)$ & $(0.2162)$ & $(0.2218)$ & $(0.2162)$ & $(0.2397)$ & $(0.2262)$ \\
\hline \multirow{2}{*}{$\begin{array}{l}\text { Observations } \\
\text { \# Firms }\end{array}$} & & 2,934 & 2,934 & 2,934 & 2,934 & 2,934 & 2,934 \\
\hline & & 474 & 474 & 474 & 474 & 474 & 474 \\
\hline \multicolumn{2}{|l|}{$\mathrm{m}_{1}$} & -5.5500 & -5.2044 & -5.3886 & -5.2046 & -5.4126 & -5.2041 \\
\hline \multicolumn{2}{|l|}{$\mathrm{p}$-value } & $(0.0000)$ & $(0.0000)$ & $(0.0000)$ & $(0.0000)$ & $(0.0000)$ & $(0.0000)$ \\
\hline \multicolumn{2}{|l|}{$\mathrm{m}_{2}$} & 0.7813 & 0.7580 & 0.7921 & 0.7350 & 0.7906 & 0.7173 \\
\hline \multicolumn{2}{|l|}{ p-value } & $(0.4346)$ & $(0.4485)$ & $(0.4283)$ & $(0.4623)$ & $(0.4292)$ & $(0.4732)$ \\
\hline \multicolumn{2}{|l|}{ Sargan } & 72.4526 & 103.6983 & 103.0169 & 102.8029 & 103.4093 & 103.3361 \\
\hline \multicolumn{2}{|l|}{ p-value } & $(0.0574)$ & $(0.2105)$ & $(0.2242)$ & $(0.2286)$ & $(0.2162)$ & $(0.2177)$ \\
\hline
\end{tabular}

Regressions are estimated using the Blundell and Bond GMM estimator for panel data.

Period analyzed: $\mathrm{t}$ includes from T-5 until T, with $\mathrm{T}$ being the year before the initial VC round.

Dependent variable: Ratio between long- plus short-term debt divided by total assets minus accounts payable. Independent Variables. Tang: Ratio between tangible fixed assets and total assets. Size: Natural logarithm of total assets. Prof: Ratio between EBIT and total assets. Vol: Moving standard deviation of the change in EBIT, computing the current and the two previous years. GO: Ratio between intangible assets and total assets. ETR: Ratio between the effective corporate tax paid and the earnings before tax. Industry: median leverage per year and industry. $\mathrm{m} 1$ and $\mathrm{m} 2$ : first and second order serial correlation test, respectively. Sargan: Sargan test of the overidentifying restrictions. Robust standard errors in brackets. Sign: shows the predicted sign of the variable.

Significance at levels $* * * 1 \%, * * 5 \%, * 10 \%$. 